\title{
Estimation of the transfer of vascular epiphytes, as a conservation strategy in the municipality of Aguazul, Casanare, Colombia.
}

Valoración de la transferencia de epífitas vasculares, como una estrategia de conservación en el municipio de Aguazul, Casanare, Colombia

\author{
Estimativa da transferência de epífitas vasculares, \\ como estratégia de conservação no município de Aguazul, \\ Casanare, Colômbia.
}

\author{
Javier Orozco Ávila1 , Argemiro Valencia Marín² \& Jhon Fredy Betancur Pérez ${ }^{3}$ \\ ${ }^{1}$ Ingeniero Agrónomo, Magister en Producción Vegetal y Mejoramiento. ${ }^{2}$ Ingeniero Forestal, Magister en Desarrollo \\ Sostenible y Medio Ambiente. ${ }^{3}$ Licenciado en Biología y Química, Especialista en Biología Molecular \\ y Biotecnología, Doctor en Ciencias Agropecuarias.
}

${ }^{1}$ Facultad de Ciencias Contables y Administrativas. 2,3Facultad de Ciencias de la Salud. 1,2,3 Centro de Investigación en Medio Ambiente y Desarrollo Sostenible (CIMAD). Universidad de Manizales. Manizales. Colombia.

1 javierorozcoavila61@gmail.com, ${ }^{2}$ argemiroforest@hotmail.com, ${ }^{3 j b e t a n c u r @ u m a n i z a l e s . e d u . c o ~}$

\begin{abstract}
Epiphytes are plants that grow mainly attached to trunks, branches of trees and shrubs. This research was conducted in the municipality of Aguazul, Casanare, Colombia, in order to evaluate conservation strategies through the transfer and recovery of vascular epiphytes. The selected population was 119 individuals. The variables were number of leaves, number of flowers, number of fruits, mortality rate, herbivory and associated entomofauna. The information collected was analyzed using descriptive statistics. As a result, it was found that the Bromeliaceae Family had the highest leaf development in the three monitorings. Bromeliaceae and Cactaceae Families did not present flowering and Orchidaceae presented low flowering. Fruiting had a similar behavior for these three families. Cactaceae Family did not present mortality, Orchidaceae recorded $2.02 \%$
\end{abstract}

and Bromeliaceae Family recorded $5.56 \%$ of mortality. As for herbivory, the orchid family filed a percentage of $0.06 \%$; the Bromeliaceae Family reported $0.11 \%$, while the cactus family did not record any kind. The entomofauna was found mainly in the Formicidae group for the three families, being the Cactaceae Family the one with a greater association, with $100 \%$. According to the results, it is possible to move the vascular epiphytic species to new habitats, which makes it a viable alternative for revegetation of the affected area with conservation purposes.

Keywords: epiphytes, insect, conservation

\section{Resumen}

Las epifitas son plantas que crecen adheridas a los troncos y ramas de árboles y arbustos 
principalmente. Esta investigación se realizó en el municipio de Aguazul, Casanare, Colombia, con el fin de evaluar estrategias de conservación mediante el traslado y rescate de epífitas vasculares. La población seleccionada fue de 119 individuos. Las variables evaluadas fueron: número de hojas, número de flores, número de frutos, porcentaje de mortalidad, herbivoría y entomofauna asociada. La información se analizó mediante estadística descriptiva. Como resultados se obtuvo que la familia Bromeliaceae presentó el mayor desarrollo foliar en los tres monitoreos. Las familias Bromeliaceae y Cactaceae no presentaron floración y en la familia Orchidaceae esta fue baja. La fructificación tuvo un comportamiento similar para las tres familias. La Familia Cactaceae no presentó mortalidad, la familia Orchidaceae registró un 2,02\%, y la familia Bromeliaceae un $5,56 \%$. En cuanto a herbivoría, la familia Orchidaceae presentó un porcentajede $0,06 \%$; la familia Bromeliaceae un 0,11\%, mientras que la familia Cactacea no registró ninguna especie. La entomofauna asociada se presentó principalmente en el orden Formicidae para las tres familias, siendo la familia Cactáceae la de mayor asociación con un $100 \%$. Según los resultados es posible trasladar especies epífitas vasculares a nuevos hábitats naturales, por lo cual es una alternativa viable de revegetación del área afectada con fines de conservación.

Palabras clave: epífitas, entomofauna, conservación

\section{Resumo}

As epifíticas são plantas que crescem nos troncos e galhos de arvores e arbustos. Esta pesquisa foi realizada na localidade de Aguazul, Casanare, Colômbia, com a finalidade de avaliar estratégias de conservação por médio de deslocamento e resgate de epifíticas vasculares. A população selecionada foi de 119 indivíduos. As variáveis avaliadas foram: número de folhas, número de flores, número de frutos, porcentagem de mortalidade, herbívoras e insetos associados. A informação foi analisada por estatística descritiva. Como resultado foi obtido que a família Bromeliaceae mostrou maior desenvolvimento foliar nos três primeiros monitoramentos. As famílias Bromeliaceae e Cactaceae não apresentaram floração e a família Orchidaceae foi baixa. A frutificação teve um comportamento similar nas três famílias. A família Cactaceae não apresentou mortalidade, a família Orchidaceae mostrou 2,02\% de mortalidade e a família Bromeliaceae $5,56 \%$. No que referente a herbívoros, a família Orchidaceae mostrou porcentagem de 0,06\%; a família Bromeliaceae de $0,11 \%$, enquanto a familia Cactacea não mostrou nenhuma espécie. Os insetos associados foram identificados principalmente da ordem Formicidae para as três famílias, a família Cactáceae teve $100 \%$ de associação. Segundo esses resultados é possível deslocar espécies epifíticas para hábitats naturais novos como alternativa viável de vegetação de áreas afetadas com fins de conservação.

Palavras-chave: epifíticas, insetos associados, conservação.

\section{Introduction}

Colombia is classified within the group of the 14 and 73 families and in ferns and related plants thecountries hosting the highest rate of biodiversity on earth, called mega-diverse countries, sharing this category with Argentina, Bolivia, Brazil, China, Costa Rica, Ecuador, India, Indonesia, Kenya, Mexico, Peru, South Africa and Venezuela (Andrade, 2011). The state of current knowledge indicates that Colombia has 927 species, 264 genera and 72 families of mosses. In hepatics plants there are records of 840 species, 140 genera and 38 families, in lichens there are 1,515 species, 253 genera re are 1,400 species, 115 genera and 32 families. The records of 26,500 species of flowering plants represent $12 \%$ of the vegetable wealth of the world (Rangel, 2005).

The Colombian Orinoco region, also called the Eastern Plains of Colombia, home of biodiversity wealth, has approximately 17 million hectares and contains three systems of land or landscapes: the foothills, alluvial plains and high plains. It belongs 
to a macro system of global importance -tropical savanna-, whose topography allows agricultural mechanization and whose soils require careful handling. Its northern border is the state of Apure in Venezuela's southwestern border; south with the Guaviare River, west to the eastern highlands and east by the Orinoco River. The administrative division of the Eastern Plains includes the departments of Meta, Vichada, Arauca and Casanare (Rippstein et al, 2001).

In Colombia, the degree of threat for a species that is under extinction is estimated according to scientific criteria, especially those developed by the International Union for Conservation of Nature (IUCN). After rigorous studies, which take into account observations and data collected over many decades of research, experts elaborated listings in which the degree of threat for each species is studied they have estimated and formulated recommendations for conservation. This information, which is published in the series Red Book of endangered species of Colombia, serves as the technical basis of Resolution 383 of February 2010, issued by the Ministry of Environment, Housing and Territorial Development (MAVDT), "in which they declare the wild species that are threaten on national territory and other determinations are taken". Several species of epiphytes are registered in Resolution 383 of 2010 (MAVDT), which makes the study and conservation of this group of plants a priority objective (Fotosíntesis, 2012).

Epiphytes are plants that grow on other plants attached to the trunks and branches of trees and shrubs, reason why they are properly called epiphytes (Greek Epique means "on" and phyte, "plant"). The host or "phorophyte" on which epiphytes grow on is used only as a support without more damage than it can cause with its abundance of branches. Therefore, epiphytic parasitic plant differs from the latter in that the latter obtains water and nutrients from its host (Granados et al, 2003). In total it is estimated that there are about 25.000 species of vascular epiphytes worldwide, which account for $5 \%$ of the total biomass of the ecosystem and have left behind the association with the land, using as support the treetops. They are mechanical parasites (Montana et al.,, 1997) and avoid the need to produce logs, stems and branches, as well as cells, organs and reinforced structures having the most plants. Epiphytism involves $10 \%$ of vascular plants, including a large number of ferns, Orchideaceae, Araceaey Bromeliaceaae, and to a lesser extent, Gesneriaceae, Piperaceae, Cactaceae, Ericaceae Melostomataceae families (Benzing, 1998).

Epiphytes play an important role in the dynamics of communities, by being stratified vertically from the trunks of the trees to the tops of the canopy, they offer a variety of niches and resources that are used by various groups of animals -ants, arthropods, amphibians, birds, etc.-, contributing to increase biodiversity in the communities where they are. Moreover, epiphytes accumulate large amounts of water from their leaves, providing an alternative pathway in the dynamics of this resource within the forest. In addition, the epiphytic's biomass established in the inner branches of trees, house high- essential nutrients such as phosphorus and nitrogen that are subsequently recycled, providing alternate routes to cycle nutrients and water dynamics (Ceja et al, 2008).

In accordance with the above, and given that Colombia has few investigations into the transfer of vascular epiphytes, as a strategy for biodiversity conservation, this research provided preliminary knowledge on the subject, through observational monitoring that allowed the evaluation of the development of vascular epiphytes a new habitat, as well as determine the association with this entomofauna on the site of transfer and compare the development of vascular epiphytes transferred to those present in the natural environment. Thus, this research provided information of great importance for future researches related to this area of knowledge in the country, as a strategy for conservation of an important component of the gene pool of the Colombian flora. 


\section{Materials and methods}

\section{Study location}

The research was conducted at the site of the Danubio, el Triunfo path, municipality of Aguazul in the department of Casanare, which is located at coordinates $1.164 .666 \mathrm{~m} \mathrm{E} ; 1.075 .259 \mathrm{~m} \mathrm{~N}$. At an altitude of 650 m.a.s.l. (meters above sea level) and is located in the lower foothills of the eastern slope of the Eastern Cordillera, $22 \mathrm{~km}$ in a straight line from the town of Yopal and $13 \mathrm{~km}$ from the town of Aguazul (Sinchi, 2007). The reserve and specifically the area where the replanting of epiphytes was made to rescue the "Gas transportation line Cusiana - Cupiagua", is framed in vicinity of the river Unete and occupies a strip of gallery forest, which correspond to mature and secondary forests found on the banks of rivers whose main function is protection, they have a minimum width of $20 \mathrm{~m}$ and maximum of $60 \mathrm{~m}$.

\section{Determination of the population targeted for the study}

The area where the rescue of epiphytes was performed and where the hydrocarbon industry conducts its work, is called right of way which corresponds to a strip of public or private land where pipelines cross that carry oil, its by-products or gas. On this site an inventory of epiphytes was performed, identifying 4822 individuals distributed in 62 species. Of this population, 1190 individuals were rescued, selecting and monitoring for planting $10 \%$ of this population, i.e. 119 individuals. $90 \%$ of the remaining population underwent maintenance and were monitored every six months in order to report the percentage of mortality to the Directorate of Forests and Ecosystems of the Ministry of Environment and Sustainable Development (MADS). The selection was made taking into account the phytosanitary status, vegetative state and representativeness.

\section{Selection criteria for transfer area}

For the final relocation process, it was established as a premise that the hosts were to be the same initial species or that the host will present the same characteristics of surface crust -preferably rough-, hosts presenting its bark resins were discarded. On the Danube reserve, 150 phorophytes greater than $10 \mathrm{~cm}$ in diameter at breast height (DBH) and with heights ranging between 4 and 35 $\mathrm{m}$ were located and geo-referenced, of which 138 trees were selected for the sowing. To select the site of transplantation, the following requirements had to be met: have enough forest coverage to install epiphyte culture and encourage natural reproduction. Having the presence of native epiphytes would prove the possibilities of epiphytic establishment in the area; also have the presence of bodies of water throughout the year in the immediate vicinity for constant watering of plants. Have accessibility to the site allowing the transfer of epiphytes in a vehicle and its subsequent monitoring and finally have an appropriate enclosure to prevent the entry of animals.

\section{Recollection and planting of selected individuals}

For the final relocation of epiphytic an area of 0.43 ha within the premises of the Danube was marked, at the time of planting an anti-stress treatment was performed to the rescued plants, immersing them in a solution of water with hormones at a dose of 40 drops of hormone (Hormonagro ANA) in $20 \mathrm{~L}$ of water, for five minutes. Later, 3 to 4 individuals were placed per selected phorophyte with anteriority. To quiches and orchids (Bromeliaceae and Orchidaceae families) and overall vascular epiphytes, individuals were collected with the fullest possible root system, without being detached from the substrate -branch, stem, root-. The moorings were done with power net tapes and were assigned the same seeding registration number for identification. A record of planting, in which data of brightness level, kind of phorophyte where it was planted, part of phorophyte where it was planted, georeferencing were reported within the reserve and registration number. In order to ensure proper growth of individuals, once located in the phorophytes, needlework permanent maintenance will be performed during each month, such as irrigation, fertilization and pruning, these efforts made it possible to reduce to a minimum the mortality rate of the material rescued and planted vegetable.

\section{Monitoring and analysis of information}

Trimestral monitoring, in which information on the 
number of sheets submitted by the individual, number of flowers, number of fruits, mortality rate, herbivory and the associated entomofauna. Epiphytes are not ideal elements for quantitative ecological studies, partly because their habitat and way of distribution are not appropriate for many of the methods that are commonly used for data analysis of terrestrial species. The ideal comparison can be made between the same species and sizes of phorophytes in different locations by the close relationship that occur between species of epiphytes and their phorophytes (Sugden \& Robins, 1979). Another reason why no statistical methods are enhanced in this study is the small number of individuals transferred. In work carried out by Nieder et al. (2000), only those species tested with more than a dozen individuals had statistically significant results. However, analysis of the variables was performed using descriptive statistics, which allowed us to know the behavior of individuals moved into their new environment.

\section{Results and Discussion}

\section{Overall representativeness}

In the inventory made in the right of way, a total of 4822 individuals corresponding to 62 species were identified, of which the most representativeness is given by the Tillandsia fasciculate Sw. and Tillandsia recurvata (L.)L. species, which belonging to the Bromeliaceae family, followed by Encyclia cordigera (HB \& K) Dressler of Orchidaceae, Monsteras pruceana (Schott Engl) and Araceae Family. As for the distribution of the corresponding translocated species in the Danube reservation, the Orchidaceae family is the best represented, with 27 relevant species and 14 genera, which is $83 \%$ of the transferred samples, followed by Bromeliaceae family that represented $15 \%$, with seven species of which six belong to the Tillandsia and Aechmea genera. Finally, the Cactaceae family had the lowest representation with only $1.68 \%$ (Figure 1).

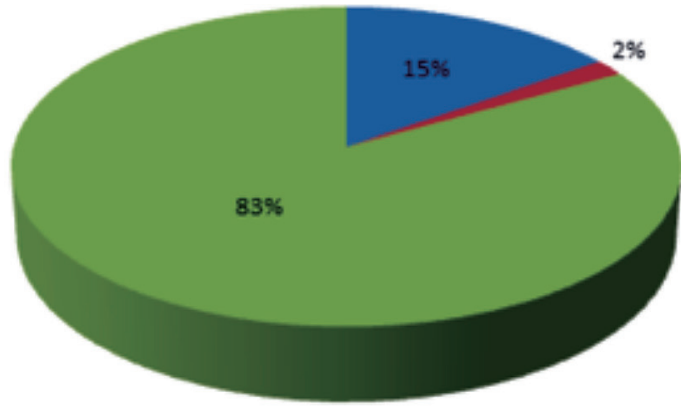

\author{
Bromeliaceae \\ - Cactaceae \\ Erchidaceae
}

Figure 1. Porcentual distribution of the genere of species transplanted to the Danubio reserve.

The 138 phorophytes in which the rescued epiphytic plants were planted, were distributed in 23 families, where trees from the Fabaceae, Melastomataceae, Rubiaceae and Anacardiaceae families accounted for the largest number of trees for this planting (Figure 2). This is because at the time of the inventory of epiphytes and phorophytes in the area of right of way, the preference for phorophytes was recorded and distribution within themselves, considering the level of exposure to light in addition to the location shaft, outer, middle or inner cup. Which allowed simulating natural conditions in relocation sites providing a better adaptation of the individuals. Other representative families were Bixaceae and Fabaceae families, the latter being the most diverse in terms of species. 


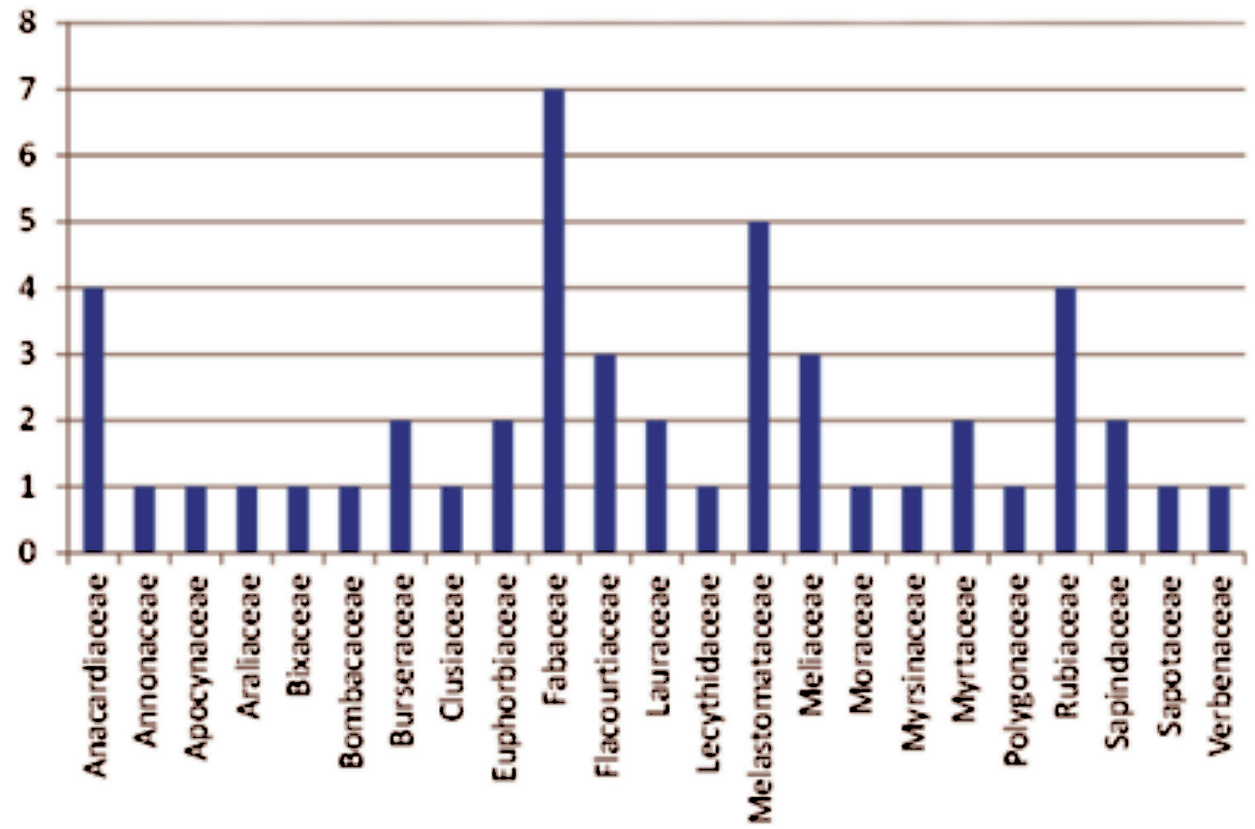

Figure 2. Number of phorophyte species distributed by families.

Significantly, according to Benzing (2008) in a defined geographical area, an epiphyte or a group of epiphytes show a strong preference for a particular group of trees, as they benefit the most their establishment and further development. Under this approach the affinity or specificity of some epiphytic species on some host species that were found at the time of the corresponding inventories are explained.

\section{Analysis of the variables}

\section{Number of leaves}

Bromeliaceae family was the one with the greater leaf development in the three monitorings, increasing in the second and third values of 35.06 and $36.33 \%$, respectively, between species with the largest leaves are Tillandsia juncea, Tillandsia rhomboidea and Tillandsia balbisiana and species with fewer leaves were Aechmea sp., Orchidaceae family presented fewer leaves to $7.6 \%$ in the first survey, $10.97 \%$ in the second and $11.35 \%$ in the third, with an increase in the second and third, Dichaea brachypoda, Epidendrum strobiliferum, bolivarense Maxilaria, Caularthron bicornutum and
Dimerandra emarginata were found to be the species with increased formation of leaves; the Catasetum callosum, Caularthron bicornutum, Galeandra cf., Minax, Polystachya foliosa, Scaphyglottis livid, Trichocentrum carthagenense and Epidendrum coronatum presented low number of leaves and in some cases no training. Keep in mind that some of these species, like Epidendrum coronatum and Trichocentrum carthagenense, have large succulent leaves, which may interfere with the growth rate. Regarding Epiphyllum phyllanthus species of the Cactaceae family, they presented a gradual increase in the three monitoring with values of $6,7.5$ and $9.5 \%$ respectively.

It is important to note that in the groups with the largest number of epiphytic species such as orchids and bromeliads, it is common to find several adaptations to drought as succulence, tanks for water uptake, photosynthesis CAM, waterproof cuticle and trichomes specialized for foliar absorption of water and nutrients (Benzing, 2008).

Considering that evaluated epiphytes come from a transplant and habitat change, during the first 
monitoring adapting to their new environment is still fresh and may generate stress that influence the vegetative development, that is associated with the month of April when such monitoring is conducted, less rainfall was presented so individuals could be exposed to water stress, which can not only cause short-term damage in the physiology of epiphytic, but it can also force these to lose leaves and thus the ability to make photosynthesis.

\section{Flowering}

In the Bromeliaceae and Cactaceae family no bloomming was recorded for any of the three monitoring; in the case of the Orchidaceae family flowering was low, showing a slight increase in the third monitoring with a value of $0.25 \%$, among the species that bloomed during the study the following were found: Encyclia cordigera (1), Encyclia leucantha (1) Trizeuxis falcata (6), Catasetum sp.2 (1), Pleurothallis sp.1 (1) and Polystachya foliosa (11). This flowering behavior could be related to climatic fluctuations and stress generated at the time of transplantation, even apart from the times of flowering, which in some cases can take years. Shakai (2001) mentions that the timing of phenological events has a major impact on survival and reproductive success of the plant. This frequency is determined not only by abiotic conditions such as temperature and humidity, but also by biotic factors including interspecific competition, interactions with other organisms, such as herbivores, pollinators, seed dispersers and interspecific competition for various means.

The Orchidaceae family, with the highest percentage of flowering, which reflects the behavior of the mayority of the tropical orchids that bloom in late winter, a time in which this monitoring was carried out and in which an increase in rainfall was recorded in the study area. Precipitation is a crucial parameter with a strong influence on the dynamics of epiphytic communities. Rain is the factor that best correlated with species richness of epiphytes (Küper et al. 2004; Cardelús et al. 2006) compared to other factors such as temperature, light intensity in the canopy and richness of trees hosts.

\section{Fructification}

In a similar way to the flowering behavior fruiting was evaluated for the three families. In the case of Bromeliaceae and Cactaceae family no fruiting occurred in any of the three monitoring conducted, as for the Orchidaceae family fruiting was low with values of $0.15 \%$ for the first monitoring, $0.20 \%$ in the second this being the highest and finally the third monitoring percentage decrease of $0.02 \%$ was recorded. Among the species with fruiting during the evaluation period are Dichaea brachypoda (1), Pleurothallis sp.1 (5), Prostechea chacaoensis (3), Scaphyglottis bidentata (5), Scaphyglottis livid (3), Encyclia cordigera (3), Maxilaria bolivarense (15) and Polystachya sp.1 (2). As has been discussed, abiotic conditions drastically influence on vegetative and productive cycles for epiphytes. The month of July when the second monitoring took place, was one of the wettest, the temperature dropped slightly and the relative humidity was higher than in the first and third monitoring, these conditions could favor fruiting in these species, and conditions of stress to which they were subjected could have influenced the biochemical and physiological responses of plants reflected in a survival mechanism, however the low fruiting could be a result of low bloom, as habitat change involves a change also in the entomofauna and therefore pollination.

\section{Mortality}

Mortality rates of individuals for each of the evaluated families were low during the three evaluations performed. Cactaceae family did not show any mortality, meanwhile Orchidaceae family presented only $2.02 \%$ at the end of the study, and Bromeliaceae family recorded $5.56 \%$ of mortality during the three constant monitoring. This would indicate that shortterm vascular epiphytes species transferred to their new habitat, morphophysiological presented adequate adaptation and that the enablement of the area was indicated, and the selection of phorophytes in which planting was performed. Significantly, lower mortality rates can indicate high affinity presented by the epiphytes with the architectural features, leaves and bark of the host. The affinity between some species epiphyes and there phorophytes can induce anatomical changes such as the creation of phellem 
reaction and phenolic substances, such as chemical and diseases establishing root growth promoter of epiphytic barrier (Aguilar, et al. 2007; Flores et al. 2014). Similarly, the dynamics of bark phorophytes species exerts an influence on the population dynamics of epiphytes in nature (Zotz \& Schmidt, 2006; Winkler, Hülber \& Hietz, 2009).

\section{Herbivory}

Herbivore related percentages were low, Orchidaceae presented in the first monitoring one percentage of $1.01 \%, 0.09 \%$ in the second and $0.06 \%$ in the third evaluation. Species presented herbivory during the three evaluations were Scaphyglottis bidentata (1), Aechmea sp (1), Camaridiumo chroleucum (1), Catasetum callosum (4), Catasetum sp (1), Encyclia cordigera (1), Epidendrum strobiliferum (1), Maxiliaria bolivarense (1), Polystachya sp.1 (1), Prostechea sp (1), Trichocentrum carthagenense (1), Caularthron bicornutum (1), Dichaea brachypoda (1) and Prosteche afragans (1). As for the Bromeliaceae family only presented, in the second monitoring, herbivory of $0.11 \%$ for the Tillandsia rhomboidea species, while the cactus family did not record any kind. Although herbivory rates are not high in the first monitoring for Orchidaceae, it should be noted that this was presented in April when rainfall was low and relatively higher temperature $\left(25.78^{\circ} \mathrm{C}\right)$ was present for the months of July and October when the remaining monitorings were performed. This fluctuation in climate may influence the behavior of some insects causing damage in certain species. Another important factor that could influence the low rates of herbivory is given by the strategy plants have developed to defend this interaction, while herbivores have developed different strategies to counter the plant defense. On the other hand, herbivory can benefit plant communities, since by reducing the number of individuals of a species the establishment of other species in the community would be permitted. Making herbivores, in some cases, promoters of biodiversity (Vega \& Peters 2003; Hernández, 2005).

\section{Association of epiphytes with insects}

The entomofauna was present throughout the assessments for the three families of epiphytes (Figure 3). The values varied for each of the monitorings, in the first, the Orchidaceae family filed a percentage of plants with insects of $35.4 \%$, followed by Bromeliaceae family with $11.1 \%$, whereas individuals belonging the Cactaceae family did not present associativity. In the second monitoring the percentage of plants with insect for the Orchidaceae family went down from 35.4 to $21,21 \%$, contrary to the percentages related to individuals in the Bromeliaceaey and Cactaceae families whose values increased to $38.89 \%$ and $50 \%$ respectively. For the third monitoring the percentage of plants with insects increased again for the Orchidaceae family with a value of $50 \%$, as for the Bromeliaceaey and Cactaceae families they show an increase in their rates with values of 50 and $100 \%$ respectively.

Fluctuations in insect populations associated with epiphytes along the monitoring plants can be linked as mentioned above with environmental factors, such as temperature, relative humidity and photoperiod factors. Temperature being one of the most important because they are poikilothermic organisms. In the analysis of the above variables, climatic variations has been emphasized in the study area, both in precipitation and temperature, relative humidity and sunshine, this abiotic factor could have influenced not only the development and growth epiphytic communities, also in populations of insect fauna associated with these plants. Moreover, the structure of the vegetation directly influences the varying input light, which increases or decreases the maximum temperature and this creates considerable differences in the study sites (Azotla \& Aguayo 1998; Becerril, 2012)

The entomofauna was represented by insects of order Formicidae, Chelicerata, Dermaptera, Blattaria, Hemiptera, Diptera, Orthoptera and Lepidoptera larvae. The highest percentages of plants associated with insects for the three families occurred in the Formicidae order, during the three evaluations, the Cactaceae family with greater association of $100 \%$, Bromeliaceae $18.52 \%$ and Orchidaceae 16,49\%. Individuals from Bromeliaceae and Orchidaceae families had a greater association with Chelicerata order with percentages of $9.26 \%$ and $10.43 \%$ respectively; these epiphyte families also had higher 
presence of insects of the order Dermaptera with values of 5.56 and $1.68 \%$. The Blattaria order was represented by $50 \%$ of individuals in the Cactaceae family associated with these insects, in a lesser percentile an association with the Bromeliaceae family is presented with $5.56 \%$. As for the Hemiptera order the highest percentage of plants was related to the Bromeliaceae family with $11.11 \%$. Bromeliaceae and
Orchidaceae families presented association with insects of the Diptera order with a percentage of 11.11 and $7.4 \%$ respectively. The order with less representativeness was Orthoptera with only $2.35 \%$ of plants in the orchid family. Finally only Bromeliaceae and Orchidaceae families presented association with Lepidoptera larvae with a percentage of 5.56 and $5.05 \%$ respectively.

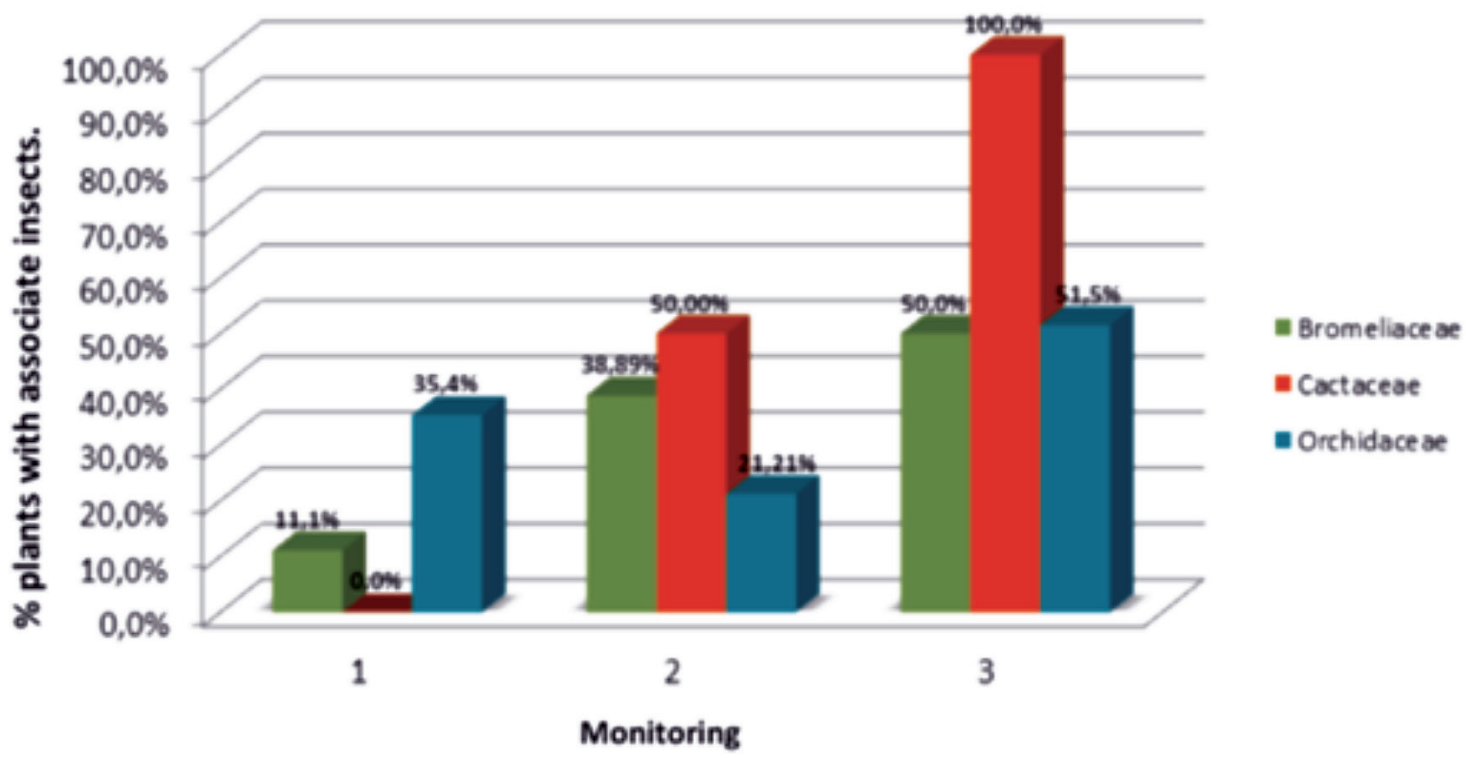

Figure 3. Percentage of plants with associated insects in the three monitoring.

Individuals corresponding to the Cactaceae and Bromeliaceae families had a higher association with insect fauna in the study area. It should be noted that the form of potted bromeliads hold water reserves throughout the year, so they can support complex food chains involving several types of organisms, such as bacteria, algae, mosses, other vascular plants, protozoa, fungi, invertebrates and some vertebrates. Bromeliads benefit from this biotic association because they can absorb nutrients from the decomposition of accumulated litter or death of other organisms, while the associated animals use the plant as a refuge and the accumulated detritus serves as a source of nutrients (Ospina et al., 2004; Liria, 2007).

According to the above, the percentages of plants associated with insects during the three evaluations can be explained, since the microclimate provided by some epiphytes, the variations of abiotic factors and phenological condition, they influence directly in these biotic relations. On the other hand, these associations with the entomofauna added to the low mortality demonstrate a suitable adjustment of the epiphyte species moved to the area of study.

\section{Conclusions and Recommendations}

According to the results obtained in this research, it is possible to move vascular epiphytes species to new natural habitats, as long as the species of tree hosts with which the epiphytes have major affinity are determined, allowing a suitable growth and development of the plants. 
The low mortality rates indicate that it is possible to ensure the survival of vascular epiphytic species once they are transferred to a new habitat. The survival of vascular epiphytes evidence that the enabling of the study area was the right choice, and the selection of phorophytes, where planting was done, presented adequate morphophysiological adaptation.

Associations between the transferred epiphytes and insect fauna of the study area show a positive interaction, which translates into an appropriate adaptability of such plants to a new habitat. The three families evaluated Cactaceae, Bromeliaceae and Orchidaceae had a high association with Formicidae order, confirming the relationship between epiphytes and formicides, mainly cactáceas.

The low rates of herbivory could be related to the transfer of epiphytic species and habitat change as interactions with macro and micro is relatively recent. Weather conditions in the area are determining the physiological, phenological behavior and interaction with the insect fauna of the area of transfer.

In cases where the construction of a pipeline or a mega-project is unavoidable, inventory and recovery of threatened species becomes potentially irreplaceable, if it is desired to document and preserve ex situ or in situ biota for the future. Thus, the transfer of epiphytic species becomes an alternative re-vegetation of the affected area for conservation to reduce the environmental impact in the area.

It is necessary to conduct research related to the transfer of epiphytic species as an alternative re-vegetation, in order to thoroughly to study the interactions that may occur in the new habitat to which they are subjected, as well as vegetative, phenological and reproductive development of these species.

\section{Cited Literature}

1. Aguilar-Rodríguez, S., Terrazas, T., Aguirre-León, E. \& Huidobro-Salas, M. E. (2007). Modificaciones en la corteza de Prosopis laevigata por el establecimiento de Tillandsia recurvata. Bol Soc Bot, 81, 27-35.

2. Andrade, G. I. (2011). Río Protegido. Nuevo concepto para la gestión de conservación de sistemas fluviales en Colombia. Gestión y Ambiente, 14(1), 65.

3. Azotla, M. V. \& Aguayo, A. G. (1998). Mating behavior of the Mexican mouse opposum (Marmosa canescens) in Cuixmala, Jalisco, Mexico. Revista Mexicana De Mastozoología (Nueva Época), 3(1), 146-147.

4. Becerril-González, M. (2012). Importancia de la fauna asociada a una planta epifita (Tillandsia polystachia) en un bosque tropical Caducifolio de México. Revista de Divulgación de la Ciencia, 9.

5. Benzing, D. H. (1998). Vulnerabilities of tropical forests to climate change: the significance of resident epiphytes. In Potential impacts of climate change on tropical forest ecosystems (pp. 379-400). Springer Netherlands.

6. Benzing, D. H. (2008). Vascular epiphytes: general biology and related biota. Cambridge University Press.

7. Cardelus, C. L., Colwell, R. K. \& Watkins, J. E. (2006). Vascular epiphyte distribution patterns: explaining the mid-elevation richness peak. Journal of Ecology, 94(1), 144-156.

8. Ceja, J., Espejo, A., García, J., López, A. R., Mendoza, A., \& Pérez, B. (2008). Las plantas epífitas, su diversidad e importancia. Ciencias, 91(091).

9. Flores-Palacios, A., Barbosa-Duchateau, C. L., Valencia-Díaz, S., Capistrán-Barradas, A. \& García-Franco, J. G. (2014). Direct and indirect effects of Tillandsia recurvata on Prosopis laevigata in the Chihuahua desert scrubland of San Luis Potosi, Mexico. Journal of Arid Environments, 104, 88-95.

10. Fotosíntesis. (2012). Proyecto Oleoducto Bicentenario. Guía ilustrada de las epifitas del tramo Araguaney-Banadía. Bogotá-Colombia, 116. p. ISBN 978-958-57536-1-7.

11. Granados-Sánchez, D., López-Ríos, G. F., HernándezGarcía, M. Á. \& Sánchez-González, A. (2003). Ecología de las plantas epífitas. Revista Chapingo. Serie ciencias forestales y del ambiente, diciembre, Vol. 9, Núm. 2, pp. 101-111.

12. Hernández - Ramírez, A. Conceptos de depredación y herbivoría. Centro de Investigaciones Tropicales Universidad Veracruzana.

13. Küper, W., Kreft, H., Nieder, J., Köster, N. \& Barthlott, W. (2004). Large-scale diversity patterns of vascular epiphytes in Neotropical montane rain forests. Journal of Biogeography, 31(9), 1477-1487. 
14. Liria, J. (2007). Fauna fitotelmata en las bromelias Aechmea fendleri André y Hohenbergia stellata Schult del Parque Nacional San Esteban, Venezuela. Revista peruana de biología, 14(1), 33-38.

15. Montana, C., Dirzo, R., \& Flores, A. (1997). Structural parasitism of an epiphytic bromeliad upon Cercidium praecox in an intertropical semiarid ecosystem. Biotropica, 29(4), 517-521.

16. Nieder, J., Engwald, S., Klawun, M. \& Barthlott, W. (2000). Spatial Distribution of Vascular Epiphytes (including Hemiepiphytes) in a Lowland Amazonian Rain Forest (Surumoni Crane Plot) of Southern Venezuela 1. Biotropica, 32(3), 385-396.

17. Ospina-Bautista, F., Estévez-Varón, J. V., Betancur, J., \& Realpe-Rebolledo, E. (2004). Estructura y Composición de la comunidad de macro invertebrados acuáticos asociados a Tillandsia turneri Baker (Bromeliaceae) en un bosque Alto Andino Colombiano. Acta Zoológica Mexicana, 20(1), 153-166.

18. Rangel, J. O. (2005). La biodiversidad de Colombia. Palimpsestvs: Revista de la Facultad de Ciencias Humanas, (5).

19. Rippstein, G., Escobar, G. \& Motta, F. M. (2001). Agroecología y biodiversidad de las sabanas en los Llanos Orientales de Colombia (No. 322). CIAT.
20. Shakai, S. (2001). Phenological diversity in tropical forests. Population Ecology, 43(1), 77-86.

21. Sinchi, I., IDEAM, IGAC, IAvH, INVEMAR, \& IIAP. (2007). Ecosistemas continentales, costeros y marinos de Colombia.

22. Sugden, A. M. \& Robins, R. J. (1979). Aspects of the ecology of vascular epiphytes in Colombian cloud forests, I. The distribution of the epiphytic flora. Biotropica, 173-188.

23. Vega, E. \& Peters, E. (2003). Conceptos generales sobre el disturbio y sus efectos en los ecosistemas. Conservación de ecosistemas templados de montaña de México. O. Sánchez, E. Vega, E. Peters, O. MonroyVilchis (eds). Diplomado en Conservación, manejo y aprovechamiento de vida silvestre. Instituto Nacional de Ecología/SEMARNAT. México, 137-151.

24. Winkler, M., Hülber, K. \& Hietz, P. (2009). Population dynamics of epiphytic orchids in a metapopulation context. Annals of Botany, 104(5), 995-1004.

25. Zotz, G. \& Schmidt, G. (2006). Population decline in the epiphytic orchid Aspasia principissa. Biological Conservation, 129(1), 82-90.
Conflicto de Intereses Los autores declaran no tener ningún conflicto de intereses

Recibido: julio 20 de 2016 Aceptado: agosto 12 de 2016 
